\title{
Patient Decision Aids in Doctor-Patient Consultations: Treatment Decision Making on Starting Insulin
}

\author{
Zuraidah Mohd Don ${ }^{a, b^{*}}$, Ayeshah Syed ${ }^{a}$ \\ ${ }^{a}$ Department of English Language, Faculty of Languages \& Linguistics, University Malaya, Kuala Lumpur, Malaysia \\ ${ }^{b}$ Faculty of Languages and Communication, Universiti Pendidikan Sultan Idris, Tanjong Malim, Perak, Malaysia \\ *Corresponding author: zuraida@um.edu.my
}

\begin{abstract}
Patient decision aids (PDAs) are increasingly used to support treatment decision making in type 2 diabetes. However, research on PDAs generally involves quantitative analysis or focuses on physicians' communicative practices, with limited data on how PDAs are used collaboratively in doctor-patient consultations. We apply discourse analytic methods to 11 recorded consultations during which a PDA on starting insulin was used. Purposive sampling was used to select participants from different healthcare settings and demographic profiles. Our analysis first addresses general questions on PDA use in the consultations, such as when it was used or mentioned in the consultation and by whom, before categorising the turns in which the PDA is mentioned or used by doctors and patients, according to the actions being performed. Next, we focus on consultations in which the patients have already read the PDA, and analyse the sequences of talk that occur after the doctor brings the PDA into the conversation. Our analysis shows that doctor talk on the PDA not only facilitated information provision, but also allowed doctors to elicit and explore the patient's knowledge and perspectives. However, the kinds of questions that doctors asked tend to limit patient participation, and their focus on the PDA at times overshadowed patient contributions. More attention to doctors' discursive choices can facilitate more patient-centred practices in using PDAs.
\end{abstract}

Keywords: Doctor-patient talk, patient decision aid; discourse analysis; type 2 diabetes.

(C) 2017 Penerbit UTM Press. All rights reserved

\subsection{INTRODUCTION}

In contrast to the traditional 'paternalistic' model of healthcare, patient-centred health care can be described as a collaborative effort between doctors and their patients, with the emphasis on patients' psychosocial and affective factors and preferences (Robinson, Callister, Berry \& Dearing, 2008). Patient-centred medicine is delivered mainly through doctor-patient talk during the phases of the consultation, where treatment decision making is of particular concern as it determines the course of treatment a patient receives, and ultimately the patient's health. Involving patients in making decisions about their own treatment has been found to contribute to improved treatment outcomes (Brody, 1980; Winnick et al., 2005). This kind of shared decision making (SDM), with participants sharing information and discussing preferences before arriving at a mutual decision (Charles, Gafni \& Whelan, 1997; 1999), has been recognised as an ideal model for making decisions about treatment options (Barry \& Edgman-Levitan, 2012; Elwyn et al., 2012; Stacey et al., 2011).

Patient decision aids (PDAs) are increasingly being used across different clinical contexts (Stacey, et al., 2011) to promote SDM, serving the dual roles of providing patients with evidence-based information about their treatment options, and assisting patients in clarifying and communicating their values relating to these options (IPDAS, 2014). They can take the form of brochures, videos, apps or other media, and are used to facilitate communication between doctors and patients, so that the best treatment option can be decided jointly in accordance with current evidence, and taking into account patients' needs, preferences and values (Montori, Breslin, Maleska, \& Weymiller, 2007).

In this article, we examine how PDAs are used in doctor-patient consultations involving type 2 diabetes patients who have to decide whether or not to undergo insulin therapy. The aim is to find out how PDAs are used, and how the first mention of PDAs in specific turns in the consultations affects subsequent sequences of talk. However, since patient-centred approaches such as SDM are relatively new, and are associated in particular with Western societies, the question arises to what extent they are really applicable in other parts of the world. The situation in Malaysia is that type 2 diabetes is highly prevalent, affecting $20.5 \%$ of adults over 30 (Hew \& Hussein, 2012), but insulin use is relatively low, taken up by only $7.2 \%$ of patients, compared to $36 \%$ in the US (Lee, Lee \& Ng, 2012). This indicates poor control of type 2 diabetes, leaving patients at risk of developing serious complications. Barriers such as fear (Benroubi, 2011) and negative perceptions (Lee, et al., 2012) have been identified among patient groups, including in Malaysia (Hassan et al., 2013). The lack of information on doctorpatient talk in the context of type 2 diabetes treatment in Malaysia, along with the gap in research on PDA use points to the need to investigate what happens during these critical conversations in the doctor's consultation room, and provides the justification for this study. 


\subsection{LITERATURE REVIEW}

\section{Treatment Decision Making and PDAs in Routine Check-ups for Type 2 Diabetes}

Type 2 diabetes is managed over a long period of time, the aim being to control the patient's blood sugar within a targeted range in order to prevent complications such as blindness and serious infections. The first line of treatment generally involves a change of diet and exercise habits on the part of the patient, followed by the introduction of oral medications if blood sugar levels remain high. Next, insulin therapy is recommended if oral medications no longer work, or for patients who are unable to take the oral medication. Since type 2 diabetes is progressive, many patients may eventually need to start insulin therapy, which is self-administered daily by means of injection using an insulin pen. The monitoring of the patient's condition and the review of treatment if necessary are conducted during routine check-up visits every few months, depending on the patient's condition.

The long-term nature of diabetes may have implications on decision making practices, as the doctor tends to know more about the patient, both in terms of medical history and perspectives and personal circumstances. Treatment decisions may also be prolonged over several consultations (Montori, Gafni \& Charles, 2006), unlike those relating to acute medical problems, which means that diabetic patients will have acquired significant knowledge through their experience with the illness.

PDAs have been developed for several clinical conditions, including diabetes and prostate cancer, and for pre-natal screening (Abadie, et al., 200; Stacey, et al., 2011), and are regarded as "tools designed to help people participate in decision making about health care options" (IPDAS, 2014). Supplementing doctor-patient consultation with PDAs will help "create a conversation" (Montori, Breslin, Maleska, \& Weymiller, 2007), enabling patients to seek clarification on scientific information and to discuss their concerns, values and preferences. Tiedge et al (2014) conclude that the flexible use of PDAs encourages discussion, making them suitable across decision making models.

Studies on PDA use have generally involved post-consultation surveys, including questionnaires and interviews (e.g. Dolan \& Frisina, 2002; Edwards et al., 2004) and quantitative analysis using coding scales such as the RIAS and OPTION (e.g. Kaner et al., 2007; Kim et al., 2005; Wyatt et al., 2014). It was found that doctors dominated the interaction (Kaner et al., 2007), did not always use PDAs as prescribed (Abadie et al., 2009; Wyatt et al., 2014), and avoided detailed discussion of treatment options with less educated or elderly patients (Hirsch et al., 2011). By focusing on only on quantitative analysis or physician communication, the collaborative work between doctors and patients is overlooked. There are few available discourse analytic studies on PDA use, and there is limited data showing how PDAs are used collaboratively by doctors and patients in consultations. This study seeks to address the gap by examining how doctors and patients interact when the PDA is used in the consultation itself.

Interaction here is viewed as situated and jointly constructed occurring in a specific professional setting, which in this study is doctorpatient consultation involving treatment decision making. It is thus subject to specific goals and identities, interactional constraints, and inferential frameworks and procedures (see Heritage, 2005), including frameworks and procedures for decision making, doctors' legal and ethical obligation to ensure patients make informed decisions, and the exchange of information between doctors and patients, as a prerequisite for informed and shared decision making (Charles et al., 1997). Interactional practices from daily conversation including turntaking, turn-design, lexical use, and epistemics are also brought into the consultation (see e.g. Heritage, 2005; 2012).

Analysing doctor-patient talk in context allows us to examine how interaction is jointly constructed to reach consensus on the treatment decision, which is a domain of joint responsibility. Context here refers to the local context of the utterance itself and the larger interactional environment within which the utterance occurs, which "is continually being developed with each successive action" (Drew \& Heritage, 1992 , 19). Utterances are connected in sequences of actions, so that the participant's interpretation of preceding talk shapes the current talk, which in turn shapes the talk or action taken next by the participant.

\subsection{METHODOLOGY}

\section{Data, Data Collection and Transcription}

The corpus of doctor-patient talk was collected as part of the Decision Making in Insulin Therapy (DMIT) project to develop and test a PDA. Designed according to the Ottawa Decision Support Framework (O'Connor et al., 1998), the 13-page PDA provides information to patients with type 2 diabetes considering insulin therapy as a treatment option. It contains patients' concerns, comparison across treatment options, advantages and disadvantages of treatment options, an assessment of patient knowledge and understanding of treatment options, value clarification, and a section prompting a decision if the patient is ready. Spaces are provided for patients to engage with the content, by checking options or making notes on matters to be discussed with their doctors.

The data selected for analysis comes from the beta testing stage of the study, during which health care providers (HCPs) conducted consultations with type 2 diabetes patients recommended for insulin therapy. All were trained and given a guidebook on how to use the PDA, and informed that it could be used at any stage of decision making or consultation. Consultations were conducted in Malaysia between November 2012 and April 2013 in three private clinics, public community clinics, and the primary care clinic of a teaching hospital, in Seremban, Kuala Lumpur and Petaling Jaya. Fourteen consultations were audio recorded, and eleven were used as primary data for analysis.

The recorded consultations were transcribed according to Jefferson's transcription conventions (2004; see Appendix 1), with all identifying information removed. We identified all instances of talk which mentioned or made reference to the PDA (e.g., "Erm, I believe you have read the book?) or used the PDA to provide or elicit information (e.g. "Now we go to "Advantages and Disadvantages of treatment options'."). After repeated listenings and viewings, notes were prepared roughly describing the kind of action being performed in each turn (e.g. eliciting opinion), and the order of the sequence in relation to the whole consultation.

\section{Participants}

The eleven consultations involved eight doctors and four male and seven female patients aged between 37 and 73 . The doctors and patients represented the three major ethnic groups in Malaysia, Malay, Chinese and Indian. Table 1 summarises the patients' demographic profiles. 
Table 1 Participant demographic profiles (by consultation)

\begin{tabular}{lllllll}
\hline \multirow{2}{*}{ NO } & \multicolumn{5}{c}{ PATIENT } & DOCTOR \\
\cline { 2 - 7 } & Sex & Age & Ethnicity & Education & Sex & Ethnicity \\
\hline A1 & M & 51 & Indian & No formal education & F & Indian \\
A2 & F & 61 & Malay & Secondary school & F & Malay \\
A3 & M & 69 & Malay & Degree & F & Malay \\
A4 & F & 71 & Indian & Primary School & F & Malay \\
B5 & F & 37 & Indian & Diploma & F & Malay \\
B7 & M & 68 & Chinese & Primary School & F & Malay \\
B8 & F & 70 & Indian & Secondary School & F & Malay \\
B15 & F & 50 & Indian & Primary School & F & Indian \\
C12 & F & 69 & Chinese & Secondary School & M & Indian \\
C11 & F & 54 & Chinese & Primary School & F & Chinese \\
C14 & M & 57 & Chinese & Diploma & F & Chinese \\
\hline
\end{tabular}

Consultations were largely conducted in English or Malay with some code-switching as one might expect in a Malaysian context. In a situation where either the speaker or the addresses is less than fully proficient in the language being used, codeswitching can make communication more effective, especially if the language switched to can be understood by both.

\section{Approach}

We adopted a discourse analytic approach (Roberts \& Sarangi, 2005) to analyse recorded consultations between doctors and patients with Type 2 diabetes for whom insulin is recommended. This involved using different methods of analysis including conversation analysis, themeoriented discourse analysis and discursive psychology to examine the interactional practices of doctors and patients as they collaboratively use the PDAs in consultations during routine check-up visits. These methods share the view that people perform actions and identities through language (see e.g. Sarangi \& Roberts, 2005).

Selected extracts were analysed turn-by-turn to identify patterns and sequences, and the findings were discussed with members of the research team, which included linguists and clinicians. The analysis was conducted to illustrate how doctors and patients jointly contribute to the development of the PDA talk, and to determine whether the use of the PDA provides the interactional conditions that encourage patient participation in decision-making. This will help us identify interactional practices of the doctor and patient when the PDA is brought into the consultation, which may have implications for training. Our analysis addresses two related research questions: 1) How is the PDA used in the consultations? and 2) What sequences of talk follow the doctors' initiation of the PDA?.

The first question concerns the use of the PDA by the doctors and patients throughout the consultations, by identifying all turns and sequences of turns, and categorising them according to the action being performed. The second focuses on consultations in which the patients have read the PDA, and analyse how patients respond to doctors' initiation of the PDA into the consultation.

We analysed the first set of data using discourse analysis (Sarangi \& Roberts, 2005) to answer some general questions about PDA use within the overall structure of the consultation, including how the PDA was brought into and used in the talk, and at which stage(s) of the consultation. The next stage of analysis involved using Conversation Analysis (henceforth CA) to examine what doctors actually did with the PDAs, and how patients responded to doctors' initiation of PDA talk. CA views consultation as a dynamic process involving coconstructed activities contributed by the doctor and the patient (Heritage \& Maynard, 2006), which is compatible with key notions in medical interaction such as 'patient-centredness' and 'shared-decision making'. Findings from detailed analyses may provide important insights into how PDAs can be better utilised in interaction to support patient-centred care and facilitate SDM.

\subsection{ANALYISIS AND RESULTS}

Since there is lack of research on the use of PDAs in doctor-patient consultations, the first stage of data analysis involves giving an overview of PDA use in the consultations, which is presented in Table 2 together with details of the consultations.

\subsection{Use of PDA in Routine Check Up Visits for Type 2 Diabetes}

The PDA was introduced in the interaction in ten of the eleven consultations, its use ranging from a single turn to several turns to prolonged interaction over several sequences of turns, with doctors and patients going through the pages of the PDA together. 
Table 2 Overview of PDA use in consultations

\begin{tabular}{|c|c|c|c|c|c|c|}
\hline No & Language & $\begin{array}{l}\text { Duration } \\
\text { (min: sec) }\end{array}$ & Setting & $\begin{array}{l}\text { Was the PDA } \\
\text { used/mentioned? } \\
\text { Who initiated it? }\end{array}$ & $\begin{array}{l}\text { When was the } \\
\text { PDA first } \\
\text { mentioned? } \\
\text { (mins from start) }\end{array}$ & $\begin{array}{l}\text { At which stage (s) } \\
\text { of consultation } \\
\text { was the PDA } \\
\text { mentioned? }\end{array}$ \\
\hline A1 & $\begin{array}{l}\text { Malay and } \\
\text { some English }\end{array}$ & $13: 41$ & & Yes, By Dr & $03: 25$ & Beginning only \\
\hline A2 & Malay & $7: 44$ & & No & $\mathrm{n} / \mathrm{a}$ & $\mathrm{n} / \mathrm{a}$ \\
\hline A3 & English & $12: 26$ & $\begin{array}{l}\text { Private } \\
\text { Clinic }\end{array}$ & Yes, By Dr & 00:04 & Beginning only \\
\hline A4 & $\begin{array}{l}\text { English and } \\
\text { Tamil-English } \\
\text { interpreting }\end{array}$ & 05:02 & & Yes, By Dr & 00:02 & Beginning only \\
\hline B5 & Malay & $40: 13$ & & Yes, By Dr & 02:05 & $\begin{array}{l}\text { Beginning and } \\
\text { Throughout }\end{array}$ \\
\hline B7 & $\begin{array}{l}\text { Malay \& some } \\
\text { Cantonese } \\
\text { phrases }\end{array}$ & $21: 56$ & $\begin{array}{l}\text { Public } \\
\text { Commu }\end{array}$ & Yes, By Dr & $02: 17$ & $\begin{array}{l}\text { Beginning, } \\
\text { throughout and end }\end{array}$ \\
\hline B8 & $\begin{array}{l}\text { English \& } \\
\text { some Malay }\end{array}$ & 21:04 & $\begin{array}{l}\text { nity } \\
\text { Clinic }\end{array}$ & Yes, By Dr & $06: 20$ & $\begin{array}{l}\text { Middle } \\
\text { throughout }\end{array}$ \\
\hline B15 & English & 19:03 & & Yes, By Dr & $02: 46$ & $\begin{array}{l}\text { Beginning and } \\
\text { throughout }\end{array}$ \\
\hline $\mathrm{C} 11$ & English & $10: 55$ & $\begin{array}{l}\text { Primary } \\
\text { Care }\end{array}$ & Yes, By Dr & 00:00 & $\begin{array}{l}\text { Beginning, } \\
\text { throughout and end }\end{array}$ \\
\hline $\mathrm{C} 12$ & English & 06.47 & $\begin{array}{l}\text { Clinic in } \\
\text { Public }\end{array}$ & Yes, By Dr & 00:20 & $\begin{array}{l}\text { Beginning, } \\
\text { throughout and end }\end{array}$ \\
\hline $\mathrm{C} 14$ & English & $18: 56$ & Hospital & Yes, by Dr & 07:01 & Middle \\
\hline
\end{tabular}

In general, the doctors brought the PDA into the conversation within the first few minutes of the consultation. However, in two consultations, the initiation of the PDA came later in the consultation, after discussing the patient's recent blood test results (B8), and in seventh minute of the conversation (C14). In private clinic consultations (A1-4), the PDA talk occurred at the beginning of the consultation, while in the public health settings (B5-8, C11-14), it occurred at the beginning, middle and end of the consultations.

Our initial analysis has identified some general patterns of PDA use with doctors performing several actions related to the PDA, including asking questions and making statements about the PDA, and giving instruction on how to use it. Table 3 lists the different kinds of action the doctors performed in turns where the PDA was mentioned and provides examples of these turns.

Table 3 Doctors' PDA Talk

\begin{tabular}{|c|c|c|}
\hline Action/Consultation & Turn Type & Examples \\
\hline $\begin{array}{l}\text { To introduce the PDA } \\
A 1, B 7\end{array}$ & Statements & $\begin{array}{l}\text { So, } s \text { - } s \text { 'karang ini yang dia orang ada bagi kita ah, ada assistance. Kalau } \\
\text { kita perlu mula insulin. Sebab itu dia ada ini booklet. Ini dia tolong doktor, } \\
\text { tolong patient to decide kalau perlu mula dengan insulin apa } \\
\text {-Okay, ini buku cerita pasal, ah kenapa, ah, apa, bagus pasal insulin, apa tak } \\
\text { bagus pasal insulin, Ah, apa yang uncle boleh boleh pilihan lah eh? Pasal, } \\
\text { pasal kencing manis jugak ade cerita sikit, eh? }\end{array}$ \\
\hline $\begin{array}{l}\text { To check if patient can read the PDA } \\
B 7\end{array}$ & Questions & Boleh baca ini? \\
\hline $\begin{array}{l}\text { To check if patient has read PDA } \\
A 3, A 4, C 12, B 5, B 8, B 15\end{array}$ & Questions & $\begin{array}{l}\text {-Did you go through the booklet? } \\
\text {-M-mh .h so, ah macam tadi you dah baca kan? Benda ni? }\end{array}$ \\
\hline $\begin{array}{l}\text { To advise patient to read the PDA at } \\
\text { home } \\
B 7, B 8\end{array}$ & $\begin{array}{l}\text { Imperatives/ } \\
\text { Statements }\end{array}$ & $\begin{array}{l}\text { Ah, saya nak uncle baca, kalau tak paham, boleh minta anak ke sapa-sapa } \\
\text { tolong tunjukkan eh }\end{array}$ \\
\hline $\begin{array}{l}\text { To check if patient has understood } \\
\text { PDA } \\
A 4, B 5, B 15, C 11, C 12\end{array}$ & Questions & $\begin{array}{l}\text {-Okey you ada paham tak, apa yang dia tulis kat sini semua? } \\
\text {-Oh, okay, but, anyway, you understand most of the things is talking in book } \\
\text { la? }\end{array}$ \\
\hline $\begin{array}{l}\text { To elicit patient's questions on the } \\
\text { PDA } \\
B 5, B 15, C 11 \text {, }\end{array}$ & Questions & $\begin{array}{l}\text {-Okey. Kalau ada,.h ada tak, apa-apa yang you nak tanya. Ah daripada } \\
\text { soalan-soalan ni, (.) ah apa yang, apa yang you rasa macam you tak paham } \\
\text { ke, ataupun you nak tau lebih lanjut ke }\end{array}$ \\
\hline $\begin{array}{l}\text { To elicit patient's opinion on the } \\
\text { PDA } \\
A 3, A 4, C 11, C 12, C 14\end{array}$ & Questions & $\begin{array}{l}\text {-Yes, er what d'you think? A:h, what do you think of the book? } \\
\text {-So what's your, what's your finding after you read the brochure, any things } \\
\text { you want to discuss with me? }\end{array}$ \\
\hline
\end{tabular}


In contrast to the doctors' use of the PDA throughout the consultations, there were only three turns of talk in which patients initiated the topic of the PDA, as illustrated in Table 4.

Table 4 Patients' PDA talk

\begin{tabular}{|c|c|c|}
\hline Purpose & Turn Type & Examples \\
\hline $\begin{array}{l}\text { To ask about the content of the PDA } \\
B 7\end{array}$ & Question & $\begin{array}{l}\text { DR-Uncle boleh hypo, boleh kurang gula: eh? Satu lagi } \\
\text { PT-Ini-ini-ini ini buk- buku ada cakap a:h? } \\
\text { DR-Ada cakap semua. Ini saya ceritakan ni }\end{array}$ \\
\hline $\begin{array}{l}\text { To support account against insulin } \\
\text { A3 }\end{array}$ & Statement & $\begin{array}{l}\text { E:r so: even in this booklet, (.) they show a guideline where my (.) sugar } \\
\text { glucose level, is at the border-line as as well }\end{array}$ \\
\hline $\begin{array}{l}\text { To support claims of knowing } \\
\text { C11 }\end{array}$ & Statement & $\begin{array}{l}\text { DR-Hm .hh ok- I, I think I er, talked to you about this, er, the: side- } \\
\text { e:r, the complication that means the what insu- what er, high sugar } \\
\text { will cause you right? } \\
\text { PT-Yes, yes, you also have my book }\end{array}$ \\
\hline
\end{tabular}

In consultation B7, when the PDA had just been introduced to the patient, the patient asked a question about the content of the PDA. The patient, who spoke Cantonese as a first language, had forgotten to bring his spectacles, and was therefore unable to read the PDA (see e.g. Lee, Y.K., Lee, P.Y., \& Ng, C.J., 2012). The doctor was explaining the content of the PDA in Malay. As the doctor began explaining the side-effects of insulin, the patient mentioned the PDA, confirming that the side-effects were included in it. The doctor confirmed this, and then continued to explain the topic.

The following two turns of patient-initiated PDA talk occur in consultations where the patients had read the PDA, which had been given to them in a previous consultation. Both patients expressed a preference not to start insulin. In consultation A3, the patient explained why he did not want to start insulin, because his blood sugar level was at the borderline of being well-controlled. In this turn, he referred to a guideline shown in the PDA (this booklet) to support his account. In consultation C11, the doctor wanted to find out further why the patient refused to start insulin, and began exploring the patient's knowledge of the complications if her blood sugar continued to be high. Here, the patient referred to the PDA ("Yes, yes, you also have my book"), in which she had filled in notes and checked marks in the columns when reading it at home. In referring to the PDA, which was earlier handed to the doctor, the patient was asserting her knowledge, as the doctor was able to see that she had already read it and was aware of the complications.

Tables 3 and 4 show different actions performed by doctors and patients in turns of talk where the PDA was explicitly mentioned. There were also lengthy sequences of talk during which the PDA was not just a topic of conversation, but was being used as a resource in the exchange of information. When patients had not read the PDA before the consultation, the doctors went through the different sections of the PDA with the patient during the session. This occurred in consultations B5, B8 and B15.

The following two extracts show different practices in using the PDA, where the doctor explained the contents of the PDA to the patient (Extract 1) and where the doctor asked the patient to go through certain pages of the PDA during the consultation (Extract 2).

Extract 1 Going through the PDA

\begin{tabular}{|c|c|c|}
\hline $\begin{array}{l}\text { Tur } \\
\text { n }\end{array}$ & Speaker & Talk \\
\hline 426 & DR8 & So are you aware of, ah what are the: $(0.36)$ \\
\hline 427 & & target, $(0.48)$ what is supposed to be the: \\
\hline 428 & & $(0.52)$ normal blood sugar level \\
\hline 429 & & -0.77 \\
\hline 430 & DR8 & Have you ever read through this? \\
\hline 431 & & -0.24 \\
\hline 432 & DR8 & This,part of it \\
\hline 433 & & -0.52 \\
\hline 434 & P11 & No hh \\
\hline 435 & DR8 & Okay, .h so e:r the blood sugar leve:1, \\
\hline 436 & & there are two ways of finding out lah Okay? \\
\hline 437 & & One is er the one that $(0.46)$ you check, on \\
\hline 438 & & your own, you know? \\
\hline 439 & P11 & [Yah ] \\
\hline 440 & DR8 & Have you [heard] of the gluco: the- the \\
\hline 441 & & [ me]ter where you check the sugar, that is \\
\hline 442 & P11 & [Yah] \\
\hline 443 & DR8 & one,.h the other one is the blood that we \\
\hline
\end{tabular}

Extract 1 shows the doctor going through pages 7 and 8 of the PDA, entitled "Knowing your Blood Sugar". The doctor first explored the patient's knowledge on this topic, with a series of questions $(426,428,432)$. On finding out that the patient had not read this section, the doctor began explaining the contents of the PDA. 
Extract 2 Going through the PDA

\begin{tabular}{|c|c|c|}
\hline $\begin{array}{l}\text { Tur } \\
\text { n }\end{array}$ & Speaker & Talk \\
\hline 287 & P5 & $\begin{array}{l}\text { Tapi, er, yang ni ka::n, saya nak tanya } \\
\text { satu::, }\end{array}$ \\
\hline 288 & DR3 & M-m:h \\
\hline 289 & P5 & A:: enggan memulakan rawatan insulin tu:: \\
\hline 290 & DR3 & $\mathrm{m}-[\mathrm{mh}]$ \\
\hline 291 & P5 & $\begin{array}{l}\text { [ke]san sampingan dia b- berat badan kita } \\
\text { naik ke:? Tak de kan. }\end{array}$ \\
\hline 292 & DR3 & A: maceni \\
\hline 293 & P5 & M: \\
\hline 294 & DR3 & $\begin{array}{l}\text { Okey so maknanya::, a:: kita nak kena } \\
\text { explain balik lah, mungkin ada benda yang } \\
\text { Puan tak paham lagi lah, eh? }\end{array}$ \\
\hline 295 & P5 & $\begin{array}{l}\text { M:h } \\
(0.38)\end{array}$ \\
\hline 296 & DR3 & $\begin{array}{l}\text { (.) .h okey. S'karang ni, a:: s'ap saya } \\
\text { tengok eh?)) } \\
(5.117) \text { ((pages being turned }\end{array}$ \\
\hline 297 & DR3 & $\begin{array}{l}\text { Okey, 'Kesan sampingan insulin'. So kita } \\
\text { cuba bukak muka surat enam } \\
\text { ((sound of pages being turned)) (3.014) }\end{array}$ \\
\hline 298 & DR3 & $\begin{array}{l}\text { Okay. So: ini, you baca eh? ha:: okay. } \\
\text { Cuba-cuba you baca dekat sini, }(0.58) \\
(0.49)\end{array}$ \\
\hline 299 & DR3 & A::.Cuba cuba you baca. \\
\hline 300 & P5 & $\begin{array}{l}\text { Insulin boleh menyebabkan paras gula } \\
\text { anda menjadi terlalu renda::h }\end{array}$ \\
\hline 301 & DR3 & $\mathrm{M}-[\mathrm{m}: \mathrm{h}]$ \\
\hline 302 & P5 & $\begin{array}{l}\text { [Ia ] boleh berlaku sekiranya anda } \\
\text { melangkah waktu makan. }\end{array}$ \\
\hline 303 & DR3 & M::h \\
\hline 304 & P5 & $\begin{array}{l}\text { Makan terlalu sedikit atau bersenam secara } \\
\text { keterlaluan. }\end{array}$ \\
\hline
\end{tabular}

In Extract 2, the doctor and the patient were looking at page 13 of the PDA, in which there was a scale weighing the reasons for starting insulin against the reasons for not starting insulin. P5, who had just agreed to start insulin, raised an issue about weight gain as a side-effect of insulin (287-251), asking whether it was true that insulin could cause weight gain. This led the doctor to conclude that P5 had not fully understood the information on side-effects of insulin. In line 294, she said that they needed to go over some of the information again. DR3 (line 297), then asked the patient to turn back to page 6, where there was a section on "Side Effects of Insulin". DR3 then asked P5 to read the section (299). P5 began reading the section out loud in lines 300-304. Following this section (not shown), the doctor went through each point, explaining it in more detail.

In this section, we present an overview of PDA use in the data, giving examples to show the different actions performed in relation to the PDA from doctors' statements to introduce the PDA and its purpose, to doctors' questions to find out whether patients had read or understood it, and to elicit patient's opinions of the PDA. Patients, on the other hand, made minimal reference to the PDA, with only three patient-initiated turns in all the consultations. Some doctors went through the PDA during the consultation to facilitate information exchange on starting insulin. This usually involved the use of different speech acts including asking questions to assess patient knowledge, making statements and elaborating on the content of the PDA, and giving instruction to direct the patient to turn to or read different sections of the PDA.

In the following section, we examine some examples of PDA use in consultations involving patients who had read the PDA. As stated by Edwards et al. (2003), patients informed by PDAs may themselves play a strong role in influencing interactions with health care professionals. It is with this consideration that we turn our attention to the way patients respond when the doctor introduces the PDA in the consultation.

\subsection{Patient Responses to Doctors' Questions on the PDA}

In daily conversation, participants can initiate topics, and respond to topic initiations by either continuing with the topic or bringing it to a close. In medical consultations, however, patients have little control over the topic, except during the opening stage, when an opportunity for them to initiate the topic is created through doctors' general opening enquiries (Campion \& Langdon, 2004). In this study, doctors' questions on the PDA, while inviting patients' opinions, questions or concerns, also constrained patients in that the topic of discussion was determined by the doctor. This means that patients could respond in one of two ways: by remaining on the topic or by initiating a new topic, as demonstrated by the following three extracts. As video recordings were available for these three consultations, the transcriptions also indicate participants' physical actions.

The PDA was introduced in the interaction in ten of the eleven consultations, its use ranging from a single turn to several turns to prolonged interaction over several sequences of turns, with doctors and patients going through the pages of the PDA together. 
Continuing with the PDA Talk

In consultation $\mathrm{C} 14$ the PDA talk does not occur right at the beginning. The male patient (P3) starts the consultation with complaints about his previous doctor and asks for a change. The female doctor (DR3) allows the patient to air his grievances before focusing her talk on insulin therapy and the PDA. Extract 3 begins 7 minutes into the consultation.

The patient's response shows that he does not think that the PDA contributes much beyond raising awareness of injections. The doctor shifted the topic to the patient's last visit at which insulin was recommended and the patient was given the PDA to read (341). She then made an attempt to bring in the voice of the life world in the interaction by soliciting the patient's view about the PDA ("What's your findings after you read the brochure?”), and inviting him to share his concerns and asking questions (352-354).

Extract 3 Consultation C14 (Setting: Primary Care Clinic; Duration 18:56)

\begin{tabular}{|c|c|c|}
\hline 341 & DR3 & Oh, good. †So coming \\
\hline 342 & & back to our topics about this \\
\hline 343 & & [injections a:h] I, I, I think Dr. Teoh= \\
\hline 344 & P3 & $[($ (nodding $))]$ \\
\hline 345 & DR3 & $=$ has bring up to you this e: :rh, suggestion. \\
\hline 346 & & (.) When he [talked] to you about this right?= \\
\hline 347 & P3 & {$[(($ nod $))]$} \\
\hline 348 & DR3 & $=\mathrm{Ah}$, the last visit $\mathrm{la}$ and [and] ask you to read \\
\hline 349 & P3 & [M: ] \\
\hline 350 & DR3 & the brochu:re, = \\
\hline 351 & P3 & $=\mathrm{Mhm}-\mathrm{mhm}=$ \\
\hline 352 & DR3 & =and:, tch, so what's your, what's your finding \\
\hline 353 & & after you read the brochure? Anything you wanted \\
\hline 354 & & to discuss with me? or questions to $[a s k$ me?] $=$ \\
\hline 355 & P3 & {$[\mathrm{A}:: \mathrm{h}]$} \\
\hline 356 & & =nothing much that $I,[I, I]$ \\
\hline 357 & DR3 & [Did you]bring it?= \\
\hline 358 & P3 & $=\mathrm{A}: \mathrm{h}, \mathrm{ya}$, it's, it's with me, nothing much that \\
\hline 359 & & [( (leans down and looks through bag ] \\
\hline 360 & DR3 & [ Do you, do you think you want to run \\
\hline 361 & & through with [me?] \\
\hline 362 & P3 & {$[\mathrm{Ya}] \mathrm{ya}=$} \\
\hline 363 & DR3 & $=$ Anything you want to- \\
\hline 364 & P3 & Nothing much about the brochure that I have \\
\hline 365 & & not known la, ha? ((produces folder from bag)) \\
\hline 372 & DR3 & Oh-okay ((nods)) \\
\hline 373 & P3 & It's- \\
\hline 376 & DR3 & Most of the things, you means you know most \\
\hline 377 & & of the things is written down [there la.] = \\
\hline 378 & P3 & {$[Y:-y a \quad]=$} \\
\hline 379 & & =It is, it is most of the:, the: (.) \\
\hline 380 & & awareness la, how aware are you?= \\
\hline 381 & DR3 & $=\mathrm{Mm}[\mathrm{hm}]$ \\
\hline 382 & P3 & [how] aware are you, [that] having the jab \\
\hline 383 & DR3 & {$[M::]$} \\
\hline 384 & P3 & is, is, $n: 0$ fuss $l a$, actually. \\
\hline
\end{tabular}

The patient's response, a negative evaluation of the PDA "nothing much ..." in 356, is intercepted by the doctor's question (357) asking whether he has the PDA with him. The patient affirms and echoes his initial evaluation of the PDA ("Nothing much"; 356). The doctor's attempt to persuade the patient to go through the PDA with her gets a brief affirmative response, but her second attempt in 363 is intercepted by the patience's repeated negative response about the PDA which suggests that he is not interested in going through it with the doctor. In 364, the patient intercepts before the doctor can complete her turn echoing what he says earlier about the PDA: "Nothing much about the brochure that I have not known". In response to the doctor's rephrasing of his preceding utterance, the patient reformulates his evaluation and states that the PDA promotes awareness, especially of injections. The expression "no fuss la" minimises the importance of the PDA.

\section{Initiating Topic Shift}

Another possible response to the doctor's PDA talk is the patient's initiation of topic shift. CA studies of ordinary conversation show that topic shifts are usually managed collaboratively by participants over several turns (Drew \& Holt, 1998). In Extract 4 the topic shift initiated by the patient in 018 is gradually preceded by minimal verbal and non-verbal responses to the doctor's queries. Extract 5 illustrates a more sudden topic shift (005), the shift being preceded by the patient's acknowledgement. Jefferson (1993) identifies this 'minimal response-topic shift', where a participant briefly acknowledges the previous talk, before initiating a topic shift.

Extract 4 below begins 20 seconds into the consultation after a brief greeting sequence. The initiation of topic shift is preceded by several turns (017-037). 
Extract 4 Consultation C12 (Setting: Primary Care Clinic; Duration 6:47)

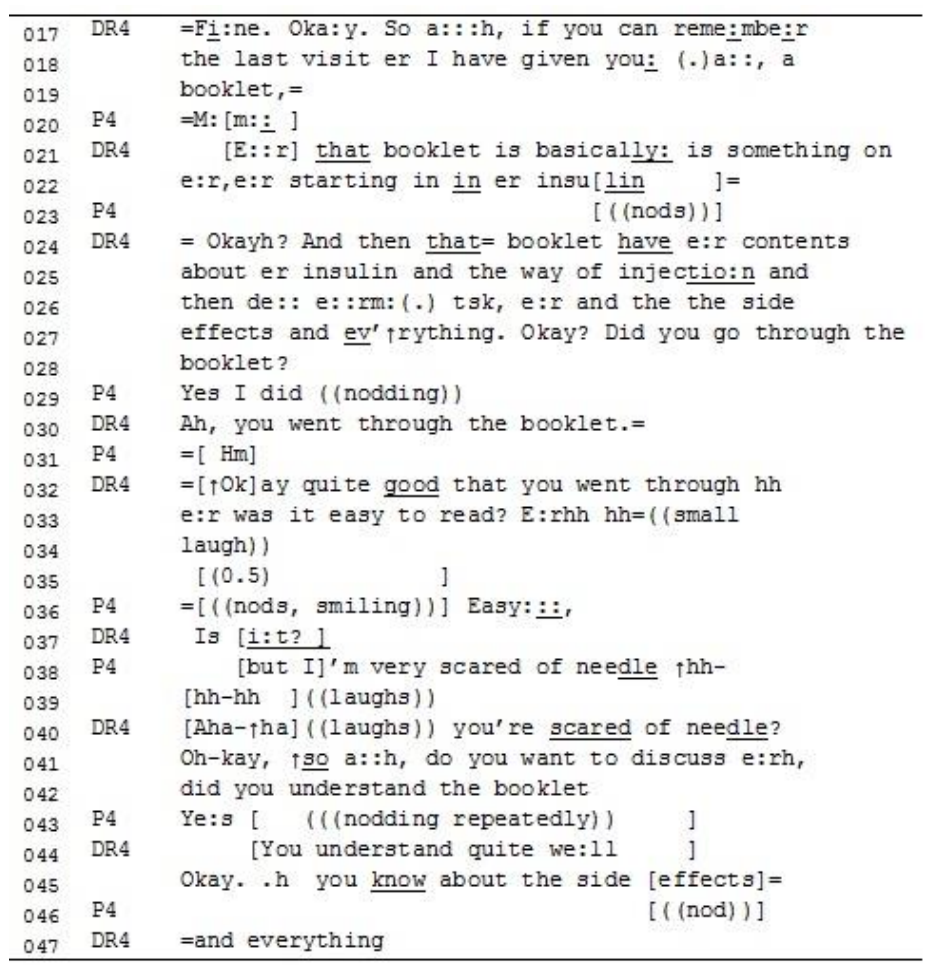

The topic initiation in 038 voices the patient's own agenda, namely her fear of needles. She uses "but" to signal the shift. Her responses before the initiation are minimal, namely continuers "mm" (020) and " $\mathrm{hm}$ " (031), nodding (023), a brief confirmation followed by nodding (029), and a one word echo (036) preceded by nodding and smiling. The patient designs her responses with a brevity aimed at allowing the doctor to continue with his turns. Her laughter accompanying the admission of fear indicates her uneasiness. While acknowledging the patient's fears, the doctor does not immediately address her concerns. The doctor responds with a confirmation-type question: "You're scared of needles?", but does not wait for the patient's response. Instead he continues to ask a series of questions about whether the patient understands the PDA and the patient responds with minimal affirmation. Only after this sequence does the doctor begin to address the patient's fears (not shown).

In Consultation C11 (Extract 5), reference to the PDA is initiated several times by the doctor, throughout the consultation, right up to the end. Extract 5 is the initial sequence of PDA talk at the beginning of the consultation.

In 003 the patient responds to the enquiry by denying that she has problems in understanding the PDA ("... no, no"), following which is a confirmation "I understand". The latched response, which intercepts the doctor's turn, stops the doctor from continuing. The change of topic signalled by "but" is initiated in 005 when the patient discloses her decision "to wait" and not to start insulin. Here, instead of keeping to the doctor's agenda, the patient voices her own agenda. The doctor acknowledges the patient's wish with "Okay", but continues with her own agenda asking the patient whether she understands the PDA (006). The patient responds with a brief affirmation and hands over her PDA to the doctor. From then on the patient only responds with a nod (014). Her lack of verbal contribution forces the doctor to focus instead on the patient's agenda and solicits confirmation from the patient, which gets a nod (016) confirming that she does not want insulin.

Extract 5 Consultation C11 (Setting Primary Care Clinic; Duration 10:55)

\begin{tabular}{|c|c|c|}
\hline 001 & DR3 & probrem about the: : $\mathrm{Y}$-you understand (.) \\
\hline 002 & & about the book or you want to- \\
\hline 003 & P5 & $\begin{aligned}= & {[\text { Yes, no, no, I understand }]=} \\
& {[((\text { looking for PDA in bag }))] }\end{aligned}$ \\
\hline 004 & DR3 & $=$ Yes, $[$ perfect $]$ \\
\hline 005 & P5 & [But I ] have to wait, now I don't want. \\
\hline $\begin{array}{l}006 \\
007\end{array}$ & DR3 & $\begin{array}{l}\text { Oh, okay, but, anyway, you understand most of the } \\
\text { things is talking in book la? }\end{array}$ \\
\hline 008 & P5 & Yes. ((nods, finds PDA \& hands it to DR3)) \\
\hline 009 & DR3 & Okay. ((takes PDA \& starts looking through it)) \\
\hline 010 & & So aright, okay so because this is all about \\
\hline 011 & & whether, what is the things= \\
\hline 012 & P5 & {$[((\operatorname{nod} s))]$} \\
\hline 013 & DR3 & $=[$ What $]$ is your concerns and everythings right $=$ \\
\hline 014 & P5 & $=(($ nods $))$ \\
\hline 015 & DR3 & So, you, you saying you don't want insulin right? \\
\hline 016 & P5 & $\operatorname{Mmh}(($ nods $))$ \\
\hline
\end{tabular}


As illustrated in Extracts 3, 4 and 5, the doctors' opening enquiries on the PDA prompt different responses from the patients, namely remaining on the initiated topic or initiating topic shifts. The initiation of topic shifts can be gradual, as in Extract 4, where the patient keeps to the doctor's agenda, responding to the doctor's question before disclosing her fear of needles; or it can be more abrupt as in Extract 5. All three patients had time between consultations to read the information. We can assume that they have made their decision about insulin therapy, and this could have influenced the way they respond to the doctor's PDA talk. In addition, doctors' opening enquiries allow the patient to express their concerns and preferences early in the discussion, which in turn allows doctors to determine how to proceed with the rest of the consultation.

\subsection{DISCUSSION}

This article examines the activity of treatment decision making in doctor-patient consultations during routine check-up visits for patients with type 2 diabetes. The patients were given the PDA to encourage participation and involvement, but an important general finding is that the interaction remained physician-centred. PDA talk was initiated by the doctor, and only one patient asked a question about the PDA. The doctors dominated the consultations, and the patients provided brief responses which were in most cases agreement, affirmation and confirmation. The focus was on the PDA, and although there were some attempts to solicit patients' values, concerns and opinions, the doctors' questions were mainly about whether patients had read and understood the content. With patients who had not read the PDA, the doctor would go through it in the consultations, interacting around the PDA to assess patient knowledge, providing information and eliciting their questions and perspectives. However, because of the small sample size and the 'observer's paradox', it is not possible to make generalisations.

As illustrated in Extracts 3, 4 and 5, the doctors' opening enquiries on the PDA prompt different responses from the patients, namely remaining on the initiated topic or initiating topic shifts. The initiation of topic shifts can be gradual, as in Extract 4, where the patient keeps to the doctor's agenda, responding to the doctor's question before disclosing her fear of needles; or it can be more abrupt as in Extract 5. All three patients had time between consultations to read the information. We can assume that they have made their decision about insulin therapy, and this could have influenced the way they respond to the doctor's PDA talk. In addition, doctors' opening enquiries allow the patient to express their concerns and preferences early in the discussion, which in turn allows doctors to determine how to proceed with the rest of the consultation.

The purpose of the PDA was to stimulate SDM, but it turned out to be physician-centred instead of patient-centred. There is a need to include elements of patient-centred consultation in physician's training and for constant feedback to the doctors to improve their practice so that they are not only informing and involving patients, but also more responsive to the preferences, needs and concerns of patients. As Maynard and Heritage (2005, p. 431) argue "... doctors can learn how their practice for soliciting concerns and problems have consequences for patients' perception of doctors' competence and credibility”, which will inevitably affect patient satisfaction.

By initiating the PDA talk early in the consultation (Extracts 1, 4 and 5), the doctors set the agenda for the consultation, namely to discuss the option of starting insulin therapy. Without explicitly mentioning "insulin therapy" or "decision", doctors could also "test the waters", creating an opportunity for patients to disclose their concerns or ask questions, before proceeding to the treatment decision. However, the patients respond differently to the opening questions on the PDA. While some may regard the questions as an opportunity to disclose fears or concerns, others may interpret them as pressure to make a decision, or to accept a treatment recommendation.

The analysis also draws attention to the importance of the timing between giving patients the PDA and making the decision. When the patient had not read the PDA, the doctor went through it with the patient, thus prolonging the consultation. However, time considerations must be balanced against the need to fulfil the information requirements of decision making, not only with respect to patient access to information, but also todoctors' elicitation of information on patient values and concerns. Multiple versions of the PDA may help address this problem, and for example a booklet could be designated for patients' home use, supplemented by a one-page PDA for the decision making consultation (Montori et al., 2007).

\subsection{IMPLICATIONS AND CONCLUSIONS}

The study is limited by its sample size, in addition to variations in the time that patients had to read the PDA before the consultation. However, the analysis and discussion bring to light two important media in doctor-patient consultation: the spoken medium, the interaction itself, and the written medium of the PDA, which require different sets of skills on the part of doctors and patients. Training doctors in PDA use is crucial to ensure that it actually facilitates shared decision making, and that doctors do not dominate the interaction at the expense of patients' concerns.

Patients' responses to doctors' opening enquiries on the PDA point to the need to establish patient knowledge in a manner which is not confrontational, and which encourages discussion. The sequencing and phrasing of the opening questions must be considered and include language and cultural aspects. For example, "Have you had a chance to read this?", followed by "What are your thoughts on insulin therapy after reading the PDA?". The latter open-ended question is designed to create an opportunity for patients to set the agenda while also focusing the topic on the treatment option being considered, rather than the PDA. In order for the PDA to be effective, the doctor has to be able to assume that the patient comes along with the necessary understanding of its content. In Extract 1, it becomes a topic in its own right, and takes up consultation time instead of saving it. In Extract 2, the doctor spends time going through the PDA, even though the patient has made it clear that she prefers another treatment option. In Extract 3, the patient's assertion that there is nothing much in the PDA almost certainly reflects what he has been able to extract from it, rather than its actual content. In Extract 4, the doctor's concern with the patient's understanding of the PDA leads him to ignore the patient's expressed fear of needles. In Extract 5, the patient does get across her wish not to start insulin therapy, but this is unconnected with the doctor's discussion of the PDA. 


\section{Ethics Statement}

This study received ethics approval from the Medical Research and Ethics Committee, Ministry of Health, Malaysia (Ref No: NMRR-101233-7299) and the Medical Ethics Committee, University of Malaya Medical Centre, Kuala Lumpur (MECRef No: 841.6).

\section{Acknowledgements}

We would like to acknowledge the University of Malaya for funding the project under which this data was collected (University Malaya Research Grant No.UMRG236/10HTM) and the Director-General of Health for allowing the study to be conducted in public health clinics under approval of the Medical Research and Ethics Committee, Ministry of Health (Reference:NMRR-10-1233-7299).

The data for this paper was collected under the Decision Making in Insulin Therapy (DMIT) research project, at the Department of Primary Care Medicine, Faculty of Medicine, University of Malaya. We would like to acknowledge the contributions of the DMIT research team, including Prof Dr Ng Chirk Jenn, Dr Lee Yew Kong, Prof Madya Dr Lee Ping Yein (Universiti Putra Malaysia), Prof Dr Khoo Ee Ming, Prof Dr Low Wah Yun and Prof Madya Dr Khatijah Lim Abdullah and Shahidatul Akmal Azmi.

\section{References}

Abadie, R., Weymiller, A.J., Tilburt, J., Shah, N.D., Charles, C., Gafni, A., et al. (2009). Clinician's Use Of The Statin Choice Decision Aid In Patients With Diabetes: A Videographic Study Nested In A Randomized Trial. Journal of Evaluation in Clinical Practice, 15, 492-497.

Benroubi, M. (2011). Fear, Guilt Feelings And Misconceptions: Barriers To Effective Insulin Treatment In Type 2 Diabetes. Diabetes Research and Clinical practice, 93, S97-S99.

Brody, D.S. (1980). The Patient's Role In Clinical Decision-Making. Annals of Internal Medicine, 93, 718-722.

Campion, P., \& Langdon, M. (2004). Achieving Multiple Topic Shifts In Primary Care Medical Consultations: A Conversation Analysis Study In UK General Practice. Sociology of Health \& Illness, 26, 81-101.

Charles, C., Gafni, A., \& Whelan, T. (1997). Shared Decision-Making In The Medical Encounter: What Does It Mean?(Or It Takes At Least Two To Tango). Social Science \& Medicine, 44, 681-692.

Clarke, G., Hall, R.T., \& Rosencrance, G. (2004). Physician-Patient Relations: No More Models. American Journal of Bioethics, 4, 16-19.

Collins, S., Drew, P., Watt, I., \& Entwistle, V. (2005). 'Unilateral'and 'Bilateral'practitioner Approaches In Decision-Making About Treatment. Social Science \& Medicine, 61, 2611-2627.

Dolan, J.G., \& Frisina, S. (2002). Randomized Controlled Trial Of A Patient Decision Aid For Colorectal Cancer Screening. Medical Decision Making, 22, 125-139.

Drew, P., \& Heritage, J. (1992). Analyzing Talk At Work: An Introduction. Cambridge: Cambridge University Press.

Drew, P., \& Holt, E. (1998). Figures of Speech: Figurative Expressions And The Management Of Topic Transition In Conversation. Language in Society, $27,495-522$.

Edwards, A., Evans, R., \& Elwyn, G. (2003). Manufactured but Not Imported: New Directions For Research In Shared Decision Making Support And Skills. Patient Education and Counseling, 50, 33-38.

Heritage, J. (2005). 'Conversation Analysis And Institutional Talk.' In Robert Sanders and Kristine Fitch (Eds.), Handbook of Language and Social Interaction (pp. 103-147). Mahwah NJ: Erlbaum.

Heritage, J. (2012). The Epistemic Engine: Sequence Organization And Territories Of Knowledge. Research on Language \& Social Interaction, 45, $30-52$.

Heritage, J., \& Robinson, J.D. (2006). The Structure Of Patients' Presenting Concerns: Physicians' Opening Questions. Health Communication, 19, 89-102.

Heritage, J. \& Maynard, D. W. (2006). 'Introduction.’ In John Heritage \& Douglas W. Maynard (Eds.), Communication in Medical Care: Interaction between Primary Care Physicians and Patients (pp. 1-21). Cambridge: Cambridge University Press.

Hew, F. N. \& Hussein, Z. (2012). Diabetes-The new Malaysian epidemic? The Star Online, Lifestyle. July 22. Retrieved on May 25, 2013 from http://thestar.com.my/health/story.asp?file=/2012/7/22/health/11702759\&sec=health

Hirsch, O., Keller, H., Krones, T., \& Donner-Banzhoff, N. (2011). Acceptance of Shared Decision Making With Reference To An Electronic Library Of Decision Aids (Arriba-Lib) And Its Association To Decision Making In Patients: An Evaluation Study. Implementation Science, 6, 70.

Jefferson, G. (1993). Caveat Speaker: Preliminary Notes On Recipient Topic-Shift Implicature. Research on Language and social interaction, 26, 1-30.

Jefferson, G. (2004). 'Glossary of Transcript Symbols With An Introduction.' In Gene H Lerner (Ed.), Conversation Analysis: Studies from the first generation (s. 1323). Philadelphia: John Benjamins.

Kaner, E., Heaven, B., Rapley, T., Murtagh, M., Graham, R., Thomson, R., et al. (2007). Medical Communication And Technology: A Video-Based Process Study Of The Use Of Decision Aids In Primary Care Consultations. BMC Medical Informatics and Decision Making, 7, 2.

Kim, Y.M., Kols, A., Martin, A., Silva, D., Rinehart, W., Prammawat, S., et al. (2005). Promoting Informed Choice: Evaluating A Decision-Making Tool For Family Planning Clients And Providers in Mexico. International Family Planning Perspectives, 162-171.

Landmark, A. M. D., Gulbrandsen, P., \& Svennevig, J. (2014). Whose Decision? Negotiating Epistemic And Deontic Rights In Medical Treatment Decisions. Journal of Pragmatics.

Lee, Y.K., Lee, P.Y., \& Ng, C.J. (2012). A Qualitative Study On Healthcare Professionals' Perceived Barriers To Insulin Initiation In A Multi-Ethnic Population. BMC Family Practice, 13,28

Lee, Y.K., Low, W.Y., \& Ng, C.J. (2013). Exploring Patient Values in Medical Decision Making: A Qualitative Study. PloS One, 8, e80051.

Lee, Y.K., Ng, C.J., Lee, P.Y., Khoo, E.M., Abdullah, K.L., Low, W.Y., et al. (2012). What Are The Barriers Faced By Patients Using Insulin? A Qualitative Study Of Malaysian Health Care Professionals' Views. Patient Preference and Adherence, 7, 103-109.

Maynard, D. G. and Heritage, J. (2005). Conversation Analysis, Doctor-Patient Interaction And Medical Communication. Medical Education. $39,428-435$.

Montori, V. M., Gafni, A., \& Charles, C. (2006). A Shared Treatment Decision-Making Approach Between Patients With Chronic Conditions And Their Clinicians: The Case Of Diabetes. Health Expectations, 9(1), 25-36.

Montori, V.M., Breslin, M., Maleska, M., \& Weymiller, A.J. (2007). Creating a Conversation: Insights From The Development Of A Decision Aid. PLoS Medicine, 4 , e233.

O'Connor A.M., Tugwell P, Wells GA, Elmslie T, Jolly E, Hollingworth G, Mcpherson R, Bunn H, Graham I, Drake E. (1998). A Decision Aid For Women Considering Hormone Therapy After Menopause: Decision Support Framework And Evaluation. Patient Education \& Counseling, 33, $267-79$.

O Connor, A.M., Llewellyn-Thomas, H.A., \& Flood, A.B. (2004). Modifying Unwarranted Variations In Health Care: Shared Decision Making Using Patient Decision Aids. Health Affairs-Millwood Va Then Bethesda Ma-, 23, Var-63.

Osvaldsson, K. (2004). On Laughter And Disagreement In Multiparty Assessment Talk. Text-Interdisciplinary Journal for the Study of Discourse, $24,517-545$.

Pappas, Y., \& Seale, C. (2009). The Opening Phase Of Telemedicine Consultations: An Analysis Of Interaction. Social Science \& Medicine, 68, $1229-1237$.

Polonsky, W.H., Fisher, L., Guzman, S., Villa-Caballero, L., \& Edelman, S.V. (2005). Psychological Insulin Resistance In Patients With Type 2 Diabetes The Scope Of The Problem. Diabetes Care, 28, 2543-2545.

Roberts, C. \& Sarangi, S. (2005). Theme-Oriented Discourse Analysis Of Medical Encounters. Medical Education. 33(6), 632-640 
Robinson, J.D. (2003). An Interactional Structure Of Medical Activities During Acute Visits And Its Implications For Patients' Participation. Health Communication, $15,27-59$.

Robinson, J., Callister, L., Berry, J. \& Dearing, K. (2008). Patient-Centered Care And Adherence: Definitions And Applications To Improve Outcomes. Journal of the American Academy of Nurse Practitioners, 20 (12), 600-607.

Robinson, J.D., \& Heritage, J. (2005). The Structure Of Patients' Presenting Concerns: The Completion Relevance Of Current Symptoms. Social Science \& Medicine, 61(2), 481-493.

Schegloff, E.A. (2007). Sequence Organization In Interaction: Volume 1: A Primer In Conversation Analysis: Cambridge University Press.

Stivers, T. (2005a). Non-Antibiotic Treatment Recommendations: Delivery Formats And Implications For Parent Resistance. Social Science \& Medicine, 60, 949-964.

Stivers, T. (2005b). Parent Resistance To Physicians' Treatment Recommendations: One Resource For Initiating A Negotiation Of The Treatment Decision. Health Communication, 18, 41-74.

Stivers, T. (2006). Treatment Decisions: Negotiations Between Doctors And Patients In Acute Care Encounters. In Robert Sanders and Kristine Fitch (Eds.), Handbook of Language and Social Interaction (pp. 279-312).

Ten Have, P. (2007). Doing Conversation Analysis: A Practical Guide. London: Sage Publications.

Warner-Garcia, S. (2014). Laughing When Nothing's Funny: The Pragmatic Use Of Coping Laughter In The Negotiation Of Conversational Disagreement. Pragmatics, $24,157-180$.

Winnick, S., Lucas, D.O., Hartman, A.L., \& Toll, D. (2005). How Do You Improve Compliance? Pediatrics, 115, e718-e724.

Wyatt, K.D., Branda, M.E., Anderson, R.T., Pencille, L.J., Montori, V.M., Hess, E.P., et al. (2014). Peering Into The Black Box: A Meta-Analysis Of How Clinicians Use Decision Aids During Clinical Encounters. Implementation Science, 9, 26.

\section{Appendix}

Appendix 1 Key to Transcription Symbols (Jefferson, 2004)

\begin{tabular}{cc}
\hline Symbol & Key \\
\hline[] & Overlapping talk \\
$()$, & No discernable interval/silence \\
between turns \\
$(0.2)$ & $\begin{array}{c}\text { Discernable silence but less than } 0.2 \text { of second } \\
\text { Silence within turns or in talk }\end{array}$ \\
Closing intonation \\
, & Slightly rising intonation \\
$?$ & Rising intonation \\
$:$, wo:rd & Elongation of preceding sound \\
Word & Emphasis \\
WORD & Spoken more loudly \\
${ }^{\circ}$ word & Spoken more softly \\
$\uparrow, \downarrow$ & Marked increase/decrease in pitch \\
Hhh & Outbreath or laughter \\
. hh & In breath or laughter \\
Hah, heh etc. & Laughter \\
wword & 'Smiley' voice \\
<word> & Talk is drawn out \\
$>$ word< & Talk is speeded up \\
$(($ word $))$ & Transcriber's notes \\
(), (word) & Transcriber unable to hear or uncertain \\
\hline
\end{tabular}

